\title{
THE INFLUENCE OF CROSS SLOPE ON HYDRAULIC CALCULATION OF DRAINAGE PAVEMENTS
}

\author{
Anadel Galamić ${ }^{1}$ \\ Mufid Tokić \\ Jasmin Hrnjadović ${ }^{3}$
}

UDK: 628.221:519.6

DOI: 10.14415/konferencijaGFS2019.073

Summary: Since the drainage of surface water from the roads is one of the essential parameters for the preservation of the planned period and the exploitation conditions of the road itself, the paper deals with the influence of the cross slope of the pavement on the hydraulic calculation drainage .

In order to efficiently and swiftly drain the surface water from the roadway, the length of the road in $L=100.0 \mathrm{~m}$ is treated, with variations in the transverse inclination. By changing the cross slope, the parameters of the hydraulic calculation are changed with respect to runoff speed. During the analysis, the hydrological parameter of the locality in which the subject is located is taken into account in this paper.

By analyzing this paper, it is to be demonstrated that the correct selection of transverse tilts of pavement structures can be of crucial importance for efficient drainage of surface water from the pavement.

Keywords: cross slope, drainage, pavement construction, hydraulic calculation, runoff speed

\section{INTRODUCTION}

Reliable and efficient road drainage is very important to ensure the stability of the lower and upper road machines. [1]

In principle, all forms of water exposure should be kept under constant control and taken to the shortest route in permanent or occasional natural watercourses. The correct selection of geometric relationships in the design and execution of the upper machine achieves faster drainage, and in this connection the degree of traffic safety increases. The climatic factor is a significant factor in determining the conditions for the construction of the planned road, especially in the winter, with low temperatures.

The moderate mountain climate prevails in the wider exploration area of the pavement structure treated in this paper. The amount of precipitation is expressed at the height of the

\footnotetext{
${ }^{1}$ Anadel Galamić, MSc. C. E. "GPP Banovići" d.o.o. Banovići, Armije BIH 36, Banovići, Bosnia and Herzegovina, tel: ++387 61887 075, e-mail: galamicanadel@gmail.com

${ }^{2}$ Mufid Tokić, MSc. C. E.

${ }^{3}$ Jasmin Hrnjadović, MSc. C. E.
} 
Савремена достигнућа у грађевинарству 23-24. април 2019. Суботица, СРБИЈА

stack of the aquifer $(\mathrm{mm})$ at a given time, provided that there is no evaporation or infiltration.

The precipitation intensity is expressed by the ratio between precipitation and unit time ( $\mathrm{mm} / \mathrm{min}$ ). Medium intensity is expressed in unit $[\mathrm{l} / \mathrm{s} / \mathrm{ha}$. For dimensioning the drainage system on the city roads is determined, for example: the drainage raster must satisfy the intensity thrust $=150(120) \mathrm{l} / \mathrm{s} / \mathrm{ha}$, for $\mathrm{t}=15 \mathrm{~min}$.

The median precipitation of the watershed is obtained by the calculation from the measurement results in the ohmometric (rainfall) cells. The coefficient of swelling $\psi$ is defined as the ratio of water in the swelling and precipitation to a given surface. The time of " $\mathrm{t}$ " is the time required for the precipitation water to reach the drainage area from the drainage area. The basic parameters for determining the input time are:

Intensity of precipitation,

The way of inflow,

The middle slope of the way inflow,

Coefficient of swelling.

\section{DEFINITION PARAMETERS}

The water from the upper surface of the road is to be drained through drains and through drainage rigs into the collecting pipe leading to the main drain receptacle. [2]

The hydraulic calculation contains the necessary information on the choice of precipitation intensity, the frequency of the spill, the coefficient and the time runoff. The hydraulic calculation is used to disposition the drainage arrangement and drainage capacity.

Appropriate drainage system achieves efficient and rapid removal of atmospheric water from the carriageway, ie fixed carriageways (in particular, water from the carriageway), and from the surrounding areas from which water flows along the way (water from other surfaces).

Therefore, two ways of drainage differ:

scattered (to the wider area),

point (at a specific place).

Scattered drainage of atmospheric water can be accomplished by overflow water over the rocks while the drainage at the points is performed by a drainage or drainage device which collects water and then drained to a common location draining away from the road area. All atmospheric water is collected in the soil, as well as in running and standing waters, or in a controlled manner in the sewerage system.

If the drainage of atmospheric water from the carriageway is carried out at a specific location, the water is not allowed to be carried directly into standing surface water, water intended for the preparation of drinking water or ground water. If the criteria for permissible levels of water contamination have exceeded, appropriate precautionary measures should be taken to keep water in carriageway and take its exit from the carriageway as drainage at a given location.

These precautionary measures depend on the type of pollution that may be permanent or extraordinary. Permanent pollution is primarily related to intermittent spillage of petroleum products, as well as to the remnants of rubber, brake linings and pouring salts that cause rain. Said contamination can be controlled by releasing water in the proper 
Contemporary achievements in civil engineering 23-24. April 2019. Subotica, SERBIA

retention of the structure. Extreme pollution, which may be due to the release of hazardous substances, may have catastrophic consequences on groundwater and the wider area.

The following conditions are relevant for scattered drainage:

- roads crossing areas characterized by grain and cracking structures, if the daily average of passenger vehicle units during the year does not exceed 12,000;

- roads crossing the limestone characteristics if the daily average of passenger vehicle units during the year does not exceed 6,000;

- the roads which cross the areas in which materials are with a bandwidth of up to $\leq 10-6$ $\mathrm{m} / \mathrm{s}$, if the daily average of passenger vehicles during the year does not exceed 40,000; - roads where atmospheric water is discharged directly into liquid or standing water if the daily average of passenger vehicle units does not exceed 12,000 during the year.

In all other cases, it is necessary to foresee a drainage method at a specific location, for the purpose of draining atmospheric waters.

Solution to the drainage is preceded by previous hydrological measurements and surveys, and good knowledge of hydrology and hydraulics are prerequisites for optimal, economical and efficient solutions.

For the drainage of significant construction, knowledge of hydrometeorological data such as:

intensity, height, duration and precipitation frequency, temperature oscillations, duration and depth of penetration of the frost.

\section{HYDROLOGICAL CALCULATION}

The amount of rainwater in direct dependence on the intensity of the precipitation, the size, the type and the inclination of the surface from which the runoff is carried out. The calculation of the quantity is based on the adopted

rainfall values from IDR curves for KS Tuzla, for a 5-minute rainfall and a 5-year return period.

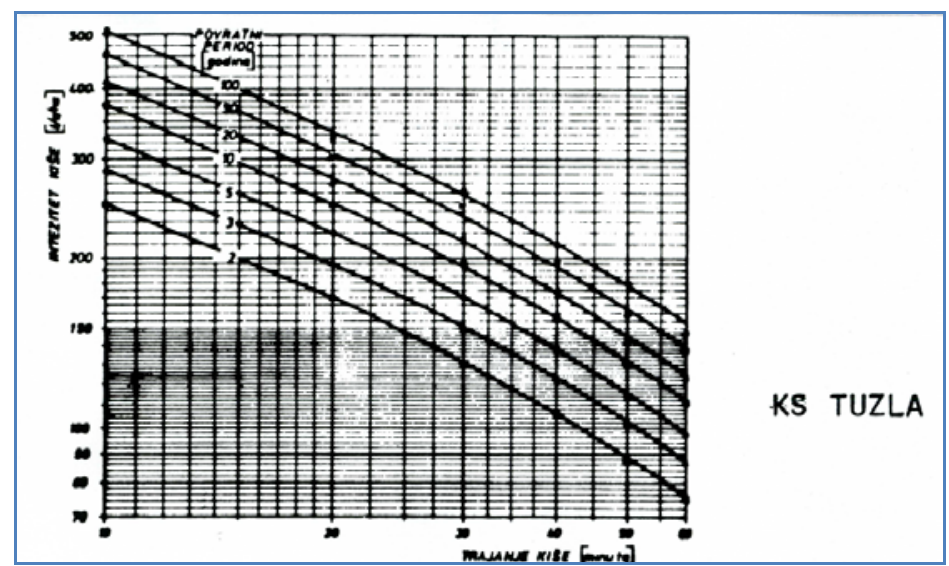

Figure 1. The graph of the dependency of the "intensity-duration-return period" according to the peak method 
Савремена достигнућа у грађевинарству 23-24. април 2019. Суботица, СРБИЈА

As already known, the maximum flow from a watershed occurs when the rainfall is equal to the time of the concentration of the watershed.

Time concentration watershed is calculated according to the formula:

$$
\mathrm{t}_{\mathrm{C}}=0,7 \cdot(1,1-\mathrm{c}) \cdot \mathrm{L}_{\mathrm{C}}^{0,5} \cdot \mathrm{S}^{-0,333} \text { (minut) }
$$

$\mathrm{L}$ - length of surface flow (m),

c - coefficient of flow,

S - slope of surface (m / m). [4] [5]

The amount of these waters is calculated according to the form:

$$
\mathrm{Q}=\mathrm{F} \cdot \mathrm{q} \cdot \psi \quad(\mathrm{l} / \mathrm{s})
$$

F- watershed area [ha],

q1 / 5- the intensity of rainfall of the return period of rainfall "one in five years" [ / s / ha], for KS Tuzla (hydroponic treatment according to the peak method) - see Figure 1, $\psi$ - coefficient of water runoff $=0.85$. [6] [7]

The following table shows the calculation of time of concentration of the watershed (traffic areas) and the calculation of the relevant amounts of total drainage of precipitation water from the same areas (Table 1).

\begin{tabular}{|c|c|c|c|c|c|}
\hline Cross slopes & C & L (m) & S sr. $(\mathbf{m} / \mathbf{m})$ & tc. calc. (min) & $\begin{array}{c}\text { tc. adopted } \\
(\mathbf{m i n})\end{array}$ \\
\hline $\begin{array}{c}\text { Cross slope } \\
1.5 \%\end{array}$ & 0.85 & 100 & 0.015 & 7.09 & 7.50 \\
\hline $\begin{array}{c}\text { Cross slope } \\
1.75 \%\end{array}$ & 0.85 & 100 & 0.018 & 6.73 & 7.00 \\
\hline $\begin{array}{c}\text { Cross slope } \\
2.0 \%\end{array}$ & 0.85 & 100 & 0.020 & 6.44 & 6.50 \\
\hline $\begin{array}{c}\text { Cross slope } \\
2.25 \%\end{array}$ & 0.85 & 100 & 0.023 & 6.19 & 6.30 \\
\hline $\begin{array}{c}\text { Cross slope } \\
2.50 \%\end{array}$ & 0.85 & 100 & 0.025 & 5.98 & 6.00 \\
\hline
\end{tabular}

Table 1: Calculation of the time of concentrations of the watershed section $l=100,00 \mathrm{~m}$

From the table can be noted that a minimum concentration occurs during the cross slope of $2.5 \%$, the maximum cross-fall of the traffic area. 
Contemporary achievements in civil engineering 23-24. April 2019. Subotica, SERBIA

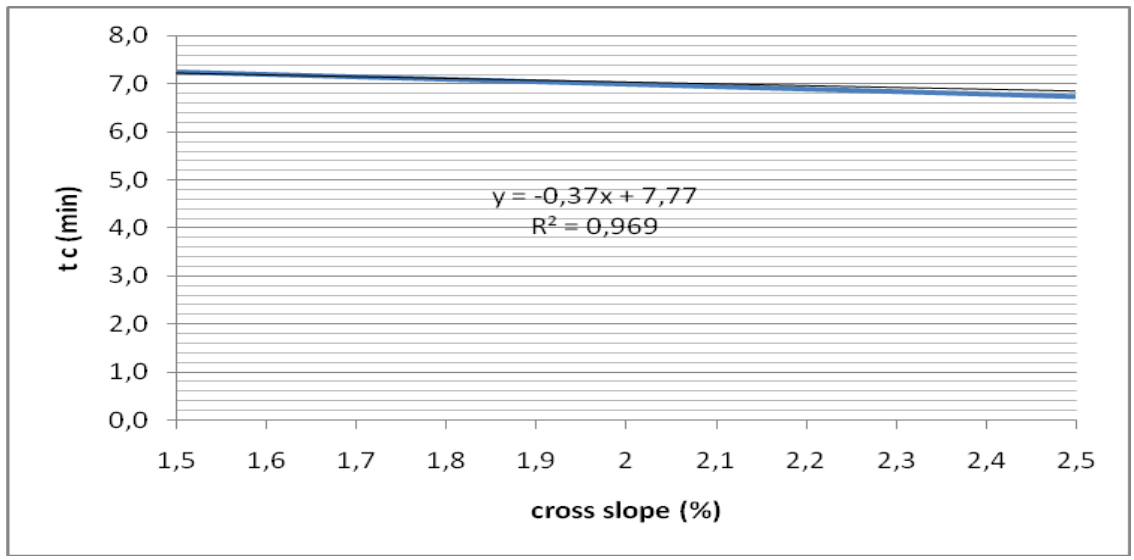

Figure 2: Runoff speed function relative to the transverse inclination of the pavement

Figure 2. shows graph of watershed concentration functions depending on the transverse inclination of the pavement, with a mathematical expression for the calculation of the concentration of the basin for any transverse inclination of the pavement.

\section{HYDRAULIC CALCULATION}

In the first phase of the hydraulic calculation, all the parameters of the rainfall collection from the coniferous surface area of the conveyor section in $L=100.0 \mathrm{~m}$, with the assumed gap of $20.0 \mathrm{~m}$.

Based on the calculation of the parameters of the rainfall from the watershed area and the obtaining of the relevant amount of drifts and the velocity of the flow, the efficiency of the drain on the section of the road was determined.

\begin{tabular}{|c|c|c|}
\hline Cross slope & $\mathbf{v a}(\mathrm{m} / \mathrm{s})$ & $\mathbf{E}$ \\
\hline $1,50 \%$ & 0,703473 & 0,661607 \\
\hline $1,75 \%$ & 0,732922 & 0,698307 \\
\hline $2,00 \%$ & 0,801418 & 0,682957 \\
\hline $2,25 \%$ & 0,783218 & 0,757154 \\
\hline $2,50 \%$ & 0,805186 & 0,780935 \\
\hline
\end{tabular}

Table 2: Runoff speed and drainage efficiency in relation to cross slope 


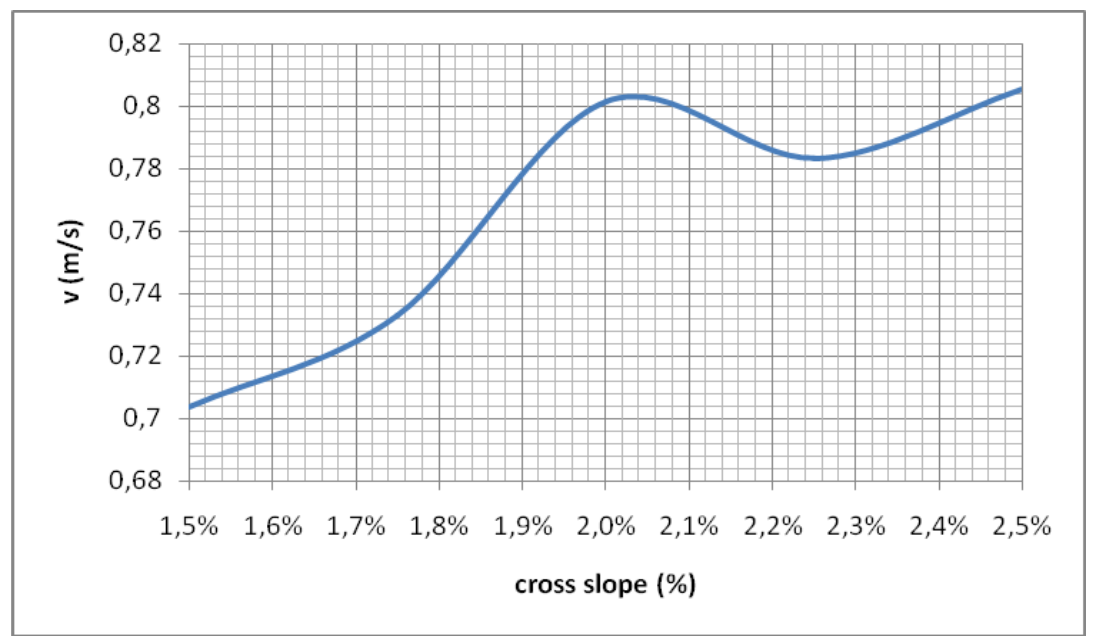

Figure 3 .: The function of runoff speed compared to the cross slope of the road structure

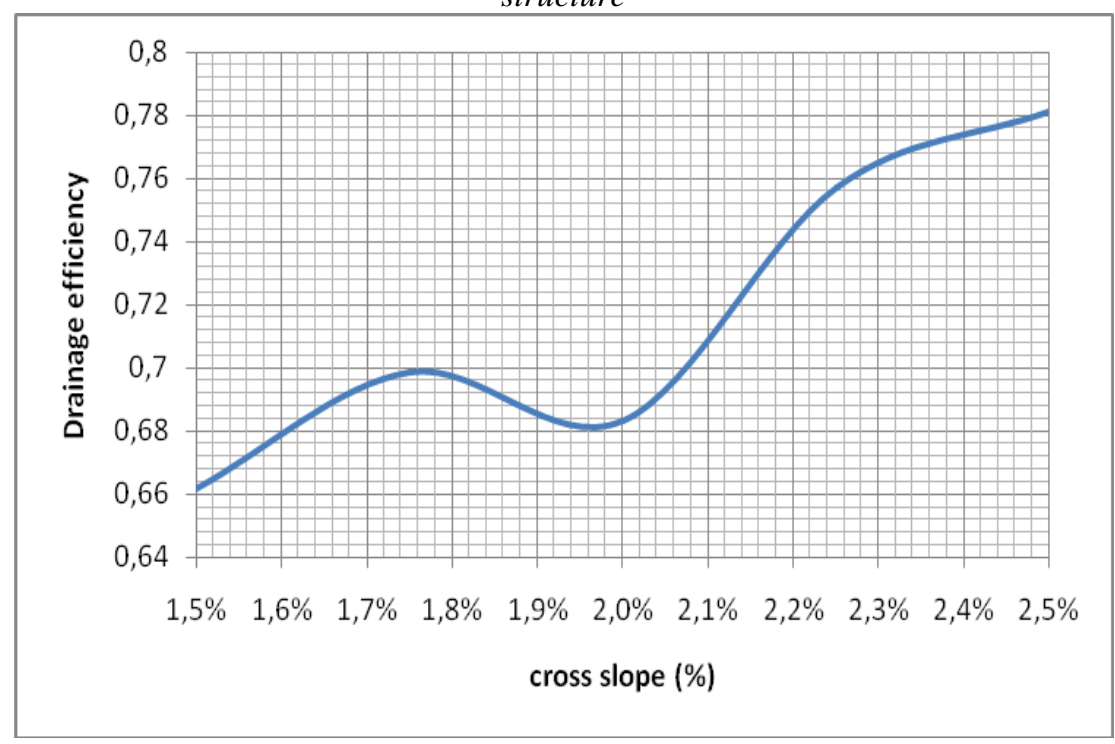

Figure 4: Function of drainage efficiency in relation to the cross slope of the pavement

In the second phase of the hydraulic calculation, hydraulic calculation of the drainage of the conveyor structure to the main recipient was carried out on the basis of the relevant rainfall values. 
INTERNATIONAL CONFERENCE

Contemporary achievements in civil engineering 23-24. April 2019. Subotica, SERBIA

\begin{tabular}{|c|c|c|c|c|c|c|c|c|c|}
\hline Name & $\begin{array}{c}\text { Lenght } \\
{[\mathrm{m}]}\end{array}$ & $\begin{array}{c}\text { Drop } \\
{[\% \text { ] }}\end{array}$ & $\begin{array}{c}\text { Inner } \\
\text { Diamet } \\
\text { er } \\
{[\mathrm{mm}]}\end{array}$ & $\begin{array}{c}\text { Total } \\
\text { flow } \\
{[\mathrm{l} / \mathrm{s}]}\end{array}$ & $\begin{array}{c}\text { Full } \\
\text { profile } \\
\text { flow } \\
{[\mathrm{l} / \mathrm{s}]}\end{array}$ & $\begin{array}{c}\text { Speed } \\
{[\mathrm{m} / \mathrm{s}]}\end{array}$ & $\begin{array}{c}\text { Full } \\
\text { profie } \\
\text { speed } \\
{[\mathrm{m} / \mathrm{s}]}\end{array}$ & $\begin{array}{c}\text { filling } \\
\text { height } \\
{[\mathrm{mm}]}\end{array}$ & $\begin{array}{c}\text { Flow } \\
\text { time } \\
{[\mathrm{min}]}\end{array}$ \\
\hline D0 & 20 & 5,01 & 188,2 & 3,91 & 22,09 & 0,61 & 0,79 & 53,11 & 0,55 \\
\hline D1 & 20 & 5,01 & 188,2 & 7,82 & 22,09 & 0,73 & 0,79 & 77,11 & 0,46 \\
\hline D2 & 20 & 5,01 & 188,2 & 11,73 & 22,09 & 0,8 & 0,79 & 97,74 & 0,41 \\
\hline D3 & 20 & 5,01 & 188,2 & 15,64 & 22,09 & 0,84 & 0,79 & 118,88 & 0,39 \\
\hline D4 & 20 & 5,01 & 188,2 & 19,55 & 22,09 & 0,85 & 0,79 & 145,04 & 0,39 \\
\hline
\end{tabular}

Table 3: Values of the hydraulic calculation to the main receiver

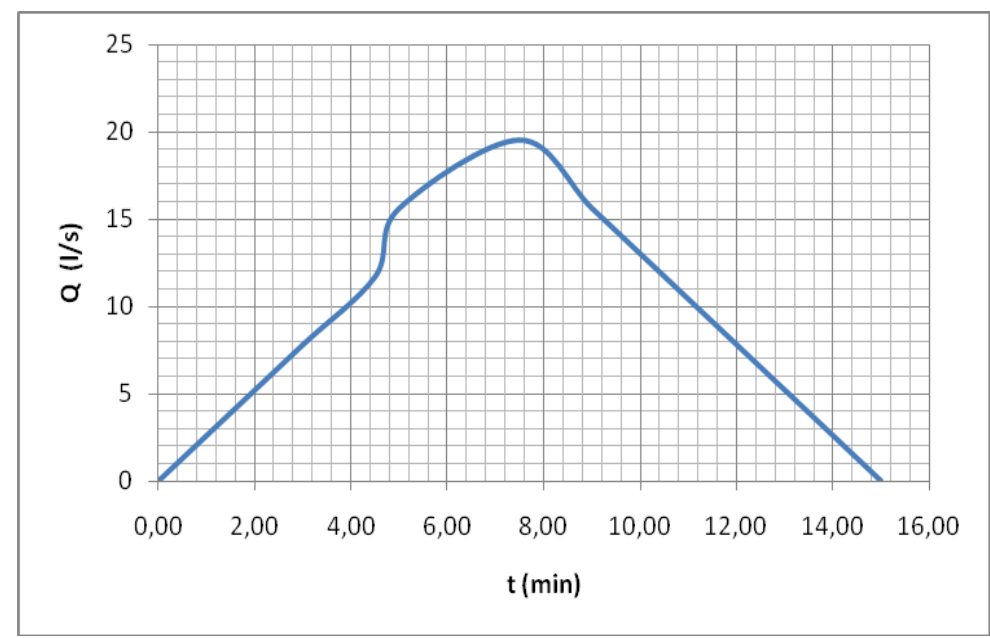

Figure 5: Function of the relevant flow rate compared to the time of the concentration of the watershed

\section{CONCLUSION}

The research carried out in this paper deals with the themes of the influence of transverse tilting of pavement structures on the hydraulic drainage calculation.

At the specific placefor which the influence parameters were made, the calculation of the flowing parameters from the watershed area of the lenght of $\mathrm{l}=100.0 \mathrm{~m}$ and the width $\mathrm{b}$ $=11.5 \mathrm{~m}$ was made.

Based on the relevant rainfall parameters and rainfall rates, the efficiency of the drain on the assumed distance of $\mathrm{l}=20.0 \mathrm{~m}$ was determined.

Since the results of the research are shown graphically, Figure 3 shows the dependence of the speed of the flowing and the transverse inclination of the pavement. From Figure 3 it is clearly seen that the increase in the inclination of the cross section of the pavement also increases the speed of the flowing for the observed rainfall. 
Савремена достигнућа у грађевинарству 23-24. април 2019. Суботица, СРБИЈА

From Figure 4 it can be seen that by increasing the inclination of the cross section of the pavement it increases the efficiency of the drain.

For cross-sectional tilting of $2.25 \%$ and $2.50 \%$, it is clear that the drainage efficiency was utilized by more than $67 \%$, which is the lower limit of drainage efficiency. For economic reasons, the distance between the drains over the observed rainfall period and the conditions used in this research can be increased. To calculate the distance of the drainage compartments, it is necessary to the calculate as presented in this study.

As the ultimate result of this research, ie the analysis of the influence of transverse inclinations on the hydraulic calculation of the drainage of the pavement, we have the dependence of the transverse inclines on the speed of runoff from the watershed and the efficiency of the drainage.

The work represents a good basis for further research in terms of proper selection of transverse tilt of pavement structures in order to efficiently drain the surface water from the pavement and to preserve the planned period and the exploitation conditions of the road itself.

\section{REFERENCES}

[1] Stanić M. Prikupljanje kišnog oticaja, Univerzitet u Beogradu, Građevinski fakultet, 2016/2017

[2] Bašić Z. Putevi, izdavačka kuća OFF-SET Tuzla, Tuzla, 2014.

[3] Despotović J. Površinski oticaj kišnih voda i slivnici kišne kanalizacije, Univerzitet u Beogradu, Građevinski fakultet, 2009.

[4] Smjernice za projektovanje, građenje, održavanje i nadzor na putevima, Sarajevo/Banja Luka, 2005.

[5] Priručnik za projektovanje puteva u republici Srbiji, sistem za odvodnjavanje, Beograd 2011.

[6] Hrelja H. Inženjerska hidrologija, Univerzitet u Sarajevu, 2007.

[7] Suljić N: Hidrotehnika- riješeni zadaci i teorijske osnove, izdavačka kuća OFF-SET Tuzla, Tuzla, 2018. 